\title{
Transnational Crime: Its Containment through International Cooperation
}

\author{
Peng Wang \\ School of law \\ King's College, University of London \\ London WC2R 2LS, England, United Kingdom \\ E-mail: peng.wang@kcl.ac.uk \\ Jingyi Wang \\ School of law \\ King's College, University of London \\ London WC2R 2LS, England, United Kingdom \\ E-mail: jingyi.wang@kcl.ac.uk
}

Canadian Center of Science and Education (CCSE) research project: Multinational Systemic Crime: A Challenge For $21^{\text {st }}$ Century. Item Number: B2009-122.

\begin{abstract}
Transnational crime, sometimes called international crime or multinational systemic crime, is more than an extension of domestic crime. In the context of globalization, transnational organized crime groups respond to market incentives and operate with cooperative relationships, which makes the multinational criminal systems become more efficient and powerful. As a result, no single country has the capability to prevent and control different kinds of transnational crime. Moreover, the containment of transnational crime through international cooperation may be an ideal way. However, there are some great challenges for international cooperation, such as different national interests and the trend of westernization. Accordingly, international cooperation should have to concern the social context and national interests of each country.
\end{abstract}

Keywords: Transnational crime, International cooperation, Containment

Transnational crime may not be a new phenomenon, however it has spread exponentially with the development of globalization during the last few years. According to the most conservative calculation, the annual profits from transnational organized crime are estimated to be between 500 to 1,500 billion dollars (Ehrenfeldt, 2003). In recent years, transnational crime, such as drug trade has posed great threat to the territory and population of many countries, especially for the Central Asia, Afghanistan and Russia (Engvall, 2006). Therefore, transnational crime has been described as the dark side of globalization (Urry, 2002). One issue cannot be neglected is that transnational criminal networks, which are far more complex and pervasive, are creating new challenges for national, local and international authorities trying to control them (Aas, 2007). Consequently, the topic about transnational criminal containment through international cooperation has become an increasingly sophisticated issue for criminologists and governments.

This paper aims to examine whether the containment of transnational crime through international cooperation is a better choice. Also, it will discuss the relationship between globalization and crime in order to pursue in-depth and comprehensive understanding of transnational crime. And it will regard transnational crime as systematic issue and offer systematic analysis of multinational systemic crime. Furthermore, it will show some great challenges for counter-crime states trying to contain international crime through international cooperation. Before the description of the containment of transnational crime through international cooperation, I will refer to some useful background information. 


\section{The profile of transnational crime}

\subsection{The preliminary issue}

One of the most important issues has always been the definition of transnational crime. The concept of transnational crime, sometimes called international crime or multinational systemic crime, is more than an extension of domestic crime (Martin and Romano, 1992). Fijnaut points out that "the adjective 'transnational' suggests that all of the types of crime mentioned recognize no national boundaries and, geographically speaking, take place in vacuum, as it were"(2000:120).

An example that plenty of countries may be involved in multinational crime systems is narcotics trafficking of Southeast Asian's Golden Triangle, where opium production and narcotics refining and trafficking have long presented a major problem (Martin and Romano, 1992). This area appears to be sophisticated and complex organization with close ties to a large number of countries on multinational level, including Thailand, Burma, Laos, China, Hong Kong, Malaysia, Taiwan, Korea, Japan, the Philippines, Singapore, India, Pakistan, Sri Lanka, Mexico, and United States (Royal Canadian Mounted Police, 1988).

Transnational crime is a social phenomenon involving people, places and institutions, which is also influenced by a variety of social, cultural, economic determinants (Findlay,2003 ). As a result, various countries have different definitions of transnational crime depending on very different philosophies. According to Martin and Romano, "transnational crime may be defined as the behavior of ongoing organizations that involves two or more nations, with such behavior being defined as criminal by at least one of these nations" (1992;15).

Transnational crime is in fact a general-purpose concept, which covers different types of crime; the main categories of transnational crime are terrorism (Adler,1999), espionage (Ranelagh, 1986; Rositzke, 1977; Corson \& Crowley, 1985), drug-trafficking (Eck \& Gersh, 2000), nuclear and arms trafficking (Begley,1996), illegal wildlife trade (Warchol, 2004), human smuggling for prostitution and low cost labor (Bensinger, 2000; Feve \& Finzel, 2001; Zhang \& Gaylord, 1996), money laundering (Gilmore, 1999), and trafficking in art, antiquities and bulk currency (US Department of Justice, 1994). Indeed, transnational crime is a complicated hybrid, thus there is some ambiguities in drawing a dividing line or separating varying types because transnational crime exists in many different hybrid forms (Ruggiero, 1996).

\subsection{Globalization and crime}

Globalization in fact has always been a widely discussed topic and there are numerous definitions of the subject in the burgeoning globalization literature (AAS, 2007). According to Scholte (2000), there are five distinguishing conceptions of globalization, such as "globalization as internationalization", "globalization as liberalization", "globalization as deterritorialization", "globalization as westernization or Americanization", "globalization as universalization". Of course none of this alters the fact that the process of globalization together with the changing role of the nation state. It is quite skeptical about the role and ability of the state as a cornerstone of political community, social theory and governance to resist the "globalization juggernut" (see for example Ohmae, 1990; Reich, 1991).

Globalization, as the process of increasing interaction and interconnectedness of societies, exerts huge favorable effects on the modern society, such as "the global economy makes different countries work as a unit in real time on a planetary scale"(Castells,1996:92), and "interconnectedness leads to 'information revolution' which has had a profound effect on all aspects of social life"(Aas,2007:9). Furthermore, the phenomenon of "global village" makes it possible for the growth of non-state actors, especially market forces or economic forces, to get over the boundary of a country and neglect state intervention.

However, the dark side of globalization is emerging. Ass points out that "the great challenges to state sovereignty come, significantly, not only from the increasing interconnected and autonomous global economy, but also from the global illicit economy" (2007: 11). In other word, globalization not only makes it possible to move goods, people and money through the global economy, but also facilitates the movement of 'dirty money' as well as the transportation of drugs , counterfeit goods, arms, illegal aliens and nuclear material (Godson and Williams, 1998). In the context of globalization, transnational organized crime groups respond to market incentives and operate with cooperative relationships regardless of their mistrust, ethnic differences and different business styles; as a result, multilateral cooperation makes them outside the structures of legitimate authority and power (Mittelman \& Johnston, 1999). Consequently, it may not be coincidental that increased interdependence between nations, the growing ease of international travel, the expansion in multinational communications, and the globalization of international financial networks have fundamentally contributed to the rise of, and continue to facilitate international criminal activities (Williams, 1994).

Moreover, globalization equally makes 'localized criminal groups', which are from different countries and regions, work as a unit and become transnational criminal organizations. As a result, cooperation among criminal organizations has improved the operational capabilities and strengthened the ability of resisting governmental control (Godson and Williams, 1998). In this case, no single country has the capability to prevent and contain different kinds of transnational crime. Consequently, transnational crime has become a severe challenge for the whole world in the $21^{\text {st }}$ century. 


\section{The containment of transnational crime through international cooperation}

\subsection{The systematic analysis of transnational crime}

Transnational crime is a systematic issue, which has threatened the integrity of financial and commercial institutions on a national and international level (Godson and Williams, 1998). Take drug trafficking systems for example, drug trafficking systems appear to be extremely sophisticated and efficient, including distribution systems, production systems, communication networks, monetary transaction systems and transportation systems. Moreover, drug trafficking systems may be interrelated with arms-traffickers, terrorist organizations, criminal groups and national intelligence agencies in a variety of ways. As a result, multinational systemic crime is often operated by complex international criminal systems, which makes it dramatically difficult for one single country to prevent and control.

\section{INSERT FIGURE 1 HERE}

Criminologists and others in field of criminology in modern society tend to subdivide crime into a great many categories, such as conventional crime, professional crime, organized crime, political crime and so on. From Figure 2, it may be hypothesized that the greater their organization and their integration with the institutions of the larger society, the greater the efficiency and power of the criminal elements involved in the various categories. One result is that such efficiency and power would seem to make their control by law enforcement agencies much more complex and difficult. Moreover, multinational systemic crime is the category of the crime with which most nation states have the least experience and are less proficient in solving and successfully prosecuting.

\section{INSERT FIGURE 2 HERE}

Transnational crime arises from the international community, which needs systematic solutions (Wang and Wang, 2009). The world cannot deal with the new century's problem by applying methods, strategies and instruments that are still rooted in the nineteenth century (James, 1989). Because of this, systematic solutions, including international research, preventing and combating strategies, which ought to be operated by the United Nations, might be the ideal way to control the relevant problems. In the same fashion, the containment of transnational crime through international cooperation is more essential than ever before in the history of mankind.

\subsection{The strategies of international cooperation}

It is clear that there is an intimate relationship between transnational crime and violence, and the greater the violence, the less the security enjoyed by citizens (Williams, 1994). Although governments exert much more efforts to fight against multinational crime and try to provide a safe environment for local and national economies, transnational criminal organizations still flourish in states during the last few years. Not surprisingly, official corruption in public and private organizations, as well as violent terrorism, are main significant issues for transnational crime networks to create their monopoly of system control and strengthen their discipline in the international system (Kelly, 1986). Sometimes it follows the fact that crime organizations may be outside the limit of national boundaries and operate beyond the legal constraint. In other cases, the corruption of public and private institutions can exclude governments from effectively deterring illegal cross-border activities. Take the drug trade and organized crime in Tajikistan for example, drug trafficking has posed tremendous effect on territory, population, state institutions, and the idea of the state (Engvall, 2006). In this case, transnational crime should be perceived as international security issue. Maybe it is the crucial moment for each government to calm down and consider the containment of transnational crime through multinational systemic solutions.

Cooperation in the field of international economics and international politics between states is more essential now than ever before for the containment of transnational crime. In order to strengthen international cooperation, a dominant strategy against criminal organizations is absolutely needed to strengthen law enforcement, harmonize regulatory and legal regimes across state boundaries, devise international conventions and establish norms. And it is no exaggeration to say that a dominant strategy may be a better way for the United Nations to control and prevent transnational crime organizations. The UN Crime Prevention and Criminal Justice Division (CPCJD) was established in 1975, and it aims to create multinational and wide-ranging measures in order to respond more comprehensively and more energetically to transnational crime (Farrington and Petrosino, 2001). According to Godson and Williams (1998:74), "a single comprehensive and coherent strategy to combat organized crime developed by a guiding authority would be ideal". A leading organization composed by every government, develops the methodologies may be the best method to understand and contain the domestic and international crime (Godson and Williams, 1998). Naturally this does not mean that all multilateral cooperation in this field should have to operated or directed by the United Nations. Actually, bilateral or triangle cooperation between individual states or non-governmental sectors should be encouraged in order to deal with regional crime systems appropriately.

On the other hand, information-sharing arrangements may directly promote international research. Furthermore, international research formulates a much clearer picture of what transnational crime actually represents in both quantitative and qualitative terms (Fijnaut, 2000). The first type of information-sharing is open-sharing, which aims to 
make analysis available to all per continent or per country or per group of countries (Godson and Williams, 1998). Indeed, one aspect cannot be ignored is that transnational crime is still an extraneous and uncontrollable phenomenon because many counter-crime states do not have the capability to understand the nature, working principles and internal structures of transnational crime groups. Open-sharing information systems, moreover, can encourage international cooperation to concentrate attention on preventing and combating multinational crime in individual countries because transnational crime issues from different social context (Fijnaut, 2000). In this case, the United Nations can deal with multinational systemic crime efficiently by using best containment strategies depending on their in-depth understanding of what causes and consequences of transnational crime are.

\section{The great challenges for international cooperation}

\subsection{Information-sharing responsibility VS National interests}

Information-sharing system is the preliminary issue for the containment of transnational crime through international cooperation. According to Godson and Williams (1998), "there is growing recognition that no country is immune from becoming a home state, host state, transshipment or service state for transnational criminal organizations." However, the great scarcity of detailed, valid, and reliable descriptive data about what the participants in criminal organizations actually do, which makes global institutions, such as United Nations, quite difficult to have an in-depth comprehension about transnational crime (Cressey, 1972). In this case, it can be argued that every nation should have the responsibility of sharing information in order to strengthen international cooperation. In addition, information-sharing system can help United Nations understand the relationships and interactions among the participants, as well as the working-principles of the organization structures.

However, some factors, such as national security, internal corruption and criminal interests, might exclude some nations from the international cooperation. Sometimes the interests of nations may be contradictory, or these interests cannot be achieved by multinational cooperation. In this case, the relationship of United Nations to the problems of doing research about multinational systemic crime can be illustrated by evasion, the secrecy, and the lack of interest (Thayer, 1969). Thus, as Musto (1987:256) presents that:

"As bad as drug trafficking might appear to Americans, when a decision involves dealing effectively with a drug-producing or exporting nation while maintaining national security interests through friendly relations with that country, national security and good relations nearly always win out over the important but less crucial issue if drugs."

Furthermore, Martin and Romano have suggested another way to look at the problem:

"such refusal may also involve the refusal of one government to cooperate with another in a major criminal investigation, not for reasons of national security but for the far more limited and self-serving reason of protecting particular official leaders, and others from embarrassment, scandal, and possible charges of criminal behavior."(1992:97)

Consequently, the refusal of multinational cooperation can protect each nation from outside review, and equally promotes the development of transnational criminal organizations.

\subsection{A dominant strategy VS Western crime control}

"A more incremental approach, if done carefully, could have very positive results"(Godson and Williams, 1998:74). In other words, a dominant strategy which is guided by the United Nations, can help the United Nations focus their attention on the structures, operations, strategies and instruments of transnational criminal organizations (ibid).

However, transnational crime always interconnected with the external environment in domestic and international forms, thus it cannot be analyzed in a vacuum circumstance. The differences among countries because of their unique cultures that sustain the project of comparative criminology are significant, which offer numerous valuable insights into similarities and differences between various criminal justice systems (Sheptycki, 2005). Therefore, it may be extremely difficult for United Nations to reach agreement of the dominant strategy to contain the multinational crime .

Moreover, western crime control may dominate the United Nations. Aas (2007) presents that "a vital task for global criminology, if it is to deserve its name, is to disturb the hegemony of Western thought within criminology, and to establish, as Cain (2000) suggests, some kind of 'interactive globalization'”. Nevertheless, Muncie (2004:154) suggests that the concept of globalization itself is essentially ethnocentric, directing our attention primarily to the developments in neo-liberal English-speaking countries. Thus, criminologists from western countries may pay no attention to the Third World and treat them in a most theoretically primitive way (Cohen, 1982). What is even worse, the Third World's countries are lacking of interests in criminological research, which can lead to a large imbalance in the production of criminological knowledge, as a result, Western countries might ignore the Third World completely (Agozino, 2004). 


\subsection{Counter-crime governments VS transnational crime organizations}

Traditionally, governments, such as the United States Federal Government, with "strong and unified political culture", "stable control of the military", "effective government control of various geographic regions", "containable corruption" and more extensive functional cooperation arrangements with other states, are always regarded as the most powerful systems (Lupsha, 1981). Unfortunately, when compared with transnational organizations, counter-crime states suffer from several disadvantages. First, they have wide-ranging purposes and constituents, while transnational crime has become an "underground empire" and enjoys one item of the flow of large profits (Williams, 1994). Although transnational crime appears to involve a complex set of attitudes, values, and behavior norms, pursuing the maximum profit might be their utmost faith. The short-term target of the US administrations after the $9 / 11$ attack, for example, focuses their attention on anti-terrorism war. Accordingly, wars against drug-trafficking or other crime may be out of their main purpose and then forgotten. In other words, it is extremely difficult for the United States to carry out a sustained and systematic campaign against multinational crime organizations according to consistent and coherent set of policies. The battle against transnational crime is, therefore, a battle of unfair competition.

Secondly, lack of experience in dealing with multinational crime is another severe challenge for governments. States are well-equipped with sufficient experience and better solutions when considering transnational crime, such as knife crime, robbery and sexual assault; transnational crime, however, is still an elusive phenomenon for many states and many people. Moreover, multinational systemic crime sometimes presents new features just as the development of modern social economy and the rise of the mass-production capitalism. One cannot ignore that transnational crime groups, unlike governments, do not have to work within the framework of regular principles, and thus operate outside the rules in regional and global scale, and are not accountable for their criminal behaviors. Transnational crime, by definition, are lacking the attributes of sovereignty, which is often an advantage rather than a constraint for it. Thereby, transnational crime groups are sovereignty-free rather than sovereignty-bound actors and "enjoy their freedom and flexibility to engage in criminal activities that are difficult for governments to regulate" (Rosenau, 1991).

\section{Conclusion}

The containment of Transnational crime through international cooperation may be a ideal way of systematic solution, because of the systematic understanding of the internal workings of transnational criminal systems, how they relate to their external environments both criminal and noncriminal, how such systems interact with each other, and how criminal organizations prosper and under which conditions they decline depending on information-sharing system among United Nations (Martin and Romano, 1992). Moreover, when the interests of United Nations are consistent, as well as these interests can be achieved through international cooperation, sharing sensitive information and strengthening multilateral cooperation will not a major obstacle (Godson and Williams, 1998). However, when compared with national interests, including national economic or political interests as well as national sensitive information, the containment of transnational crime through multinational cooperation might be a thing that cannot be achieved. Consequently, it may be argued that the prevent and control of the transnational crime through multinational cooperation would have to be consistent with the relevant social context, such as social interests, cultural characteristics, political orientation and economic interests of the implementing nations or regions. Without comprehensive consideration, however, the containment of multinational crime through multilateral cooperation may be impossible.

\section{References}

Aas, K. F. (2007). Globalization \& Crime. SAGE Publications.

Agozino, B. (2004). Imperialism, crime, and criminology: towards the decoloniasation of criminology. Crime Law \& Social Change, 41: 343-358.

Begley, S. (1996). Nuclear arms increase the threat of terrorism. In A. E. Sadler \& P. A. Winters (Eds.), Urban Terrorism (pp. 27-29). San Diego: Greenhaven Press.

Bensinger, G. J. (2000). Prostitution and trafficking in women. Crime \& Justice International, 16(46): 5-7.

Cain, M. (2000). Orientalism, Occidentalism and the Sociology of Crime. British Journal of Criminology, 40(2): 239-260.

Castells, M. (1996). The Rise of the Network Society. Oxford: Blackwell.

Cohen, S. (1982). Western Crime Control Models in the Third World: benign or Malignant?. Research in Law, deviance and Social Control, 4: 85-119.

Corson, W. R. \& Crowley, R. T. (1985). The new KGB: Engine of Soviet power. New York: William Morrow.

Cressey, D. R. (1972). Criminal organization: Its elementary forms. New York: Harper \& Row.

Eck, J. E. \& Gersh, J. S. (2000). Drug trafficking as a cottage industry. In M. Natarajan \&M. Hough (Eds.), Illegal drug markets: From research to prevention policy (pp. 241-271). Monsey, NY: Criminal Justice Press/ Willow Tree Press. 
Ehrenfeldt, R. (2003). Funding Evil: How Terrorism is Financed and How to Stop it. New York. Bonus Books.

Engvall, J. (2006). The State under siege: The Drug Trade and Organised Crime in Tajikistan. Europe-Asia Studies, 58(6): 827-854.

Farrington, D. P. \& Petrosino, D. (2001). The Campbell Collaboration Crime and Justice Group. The ANNALS of the American Academy of Political and Social Science, 578(1): 35-49.

Feve, S. \& Finzel, C. (2001). Trafficking of people. Harvard Journal on Legislation, 38(1): 279-290.

Fijnaut, C. (2000). Transnational crime and the role of the United Nations in its Containment through international cooperation: A challenge for the $21^{\text {st }}$ century. European journal of crime, criminal law and criminal justice, 8(2): 119-127.

Findly, M. (2003). The globalization of Crime: Understanding Transnational Relationship in Context. Cambridge University Press.

Giddens, A. (1990). The Consequences of Modernity. Cambridge: Polity Press.

Gilmore, W. C. (1999). Dirty money: the evaluation of money laundering counter-measures. Council of Europe Publishing.

Godson, R. and Williams, P. (1998). Strengthening Cooperation Against Transnational Crime. Survival 40(3): 66-68.

James, N. R. (1989). Turbulence in World Politics. Princeton, NJ: Princeton University Press.

Kelly, R. J. (1986). Criminal Underworlds: Looking down on Society from Below in R. J. Kelly (ed.), Organised Crime: A Global Perspective. Totowa, NJ: Rowman and Littlefield.

Lupsha, P. A. (1981). Drug trafficking: Mexico and Columbia in comparative perspective. Journal of International Affairs, 35 (1): 95-115.

Martin, J. M. and Romano, A. T. (1992). Multinational Crime-Terrorism, Espionage, Drug \&Arms Trafficking. SAGE Publications.

Mittelman, J. H. \& Johnston, R. (1999). The Globalization of Organized Crime, the Courtesan State, and the Corruption of Civil Society. Global Governance, 5: 103-126.

Muncie, J. (2004). Youth justice: globalization and multi-model governance, in T. Newburn and R. Sparks (eds) Criminal Justice and Political Cultures: National and International Dimensions of Crime Control, Cullompton: Willan.

Musto, D. F. (1987). The American disease: Origins of narcotic control. New York: Oxford University Press.

Ohmae, K. (1990). The Borderless World: Power and Strategy in the International Economy. London: Collins.

Ranelagh, J. (1986). The agency: The rise and decline of the CIA. New York: Simon \& Schuster.

Reich, R. (1991). The Work of Nations: Preparing Ourselves for $21^{\text {st }}$-Century Capitalism. New York: Alfred A. Knopf.

Rosenau, J. (1991). Turbulence in World Politics. Princeton, NJ: Princeton University Press.

Rositzke, H. A. (1977). The CIA's secret operations. New York: Reader's Digest Press.

Royal Canadian Mounted Police. (1988). National Drug intelligence estimate 1986/87. Ottawa, Ontario, Canada.

Ruggiero, V. (1996). organized and Corporate Crime in Europe: Offers that Can't be Refused. Crime, Law and Social Change, 31(2): 159-163.

Scholte, J. A. (2000). Globalization: a critical introduction. Journal of international studies, 29(2): 536-538.

Sheptycki, J. (2005). Relativism, transnationalisation and comparative criminology, in J. W. E. Sheptycki and A. Wardak (eds) Transnational \& Comparative Criminology. London: Glasshouse Press.

Thayer, G. (1969). The war business: The international trade in armaments. New York: Simon \& Schuster.

Urry, J. (2002). The global complexities of September $11^{\text {th }}$. Theory, Culture \& Society, 19(4): 57-69.

US Department of Justice (Drug Enforcement Administration, Strategic Intelligence Section) (1994). Asian money movement methods. Washington, DC: Author.

Wang, P. and Wang, J. Y. (2009). Criminology Analysis from the Perspective of Chinese Ancient Materialism. Asian Social Science, 5(4): 108-113.

Williams, P. (1994). Transnational Criminal Organizations and International Security. Survival, 36(1): 96-113.

Zhang, S. X. \& Gaylorn, M. S. (1996). Bound for the golden mountain: The social organization of Chinese alien smuggling. Crime, Law, and Social Change, 25 (1): 1-16. 


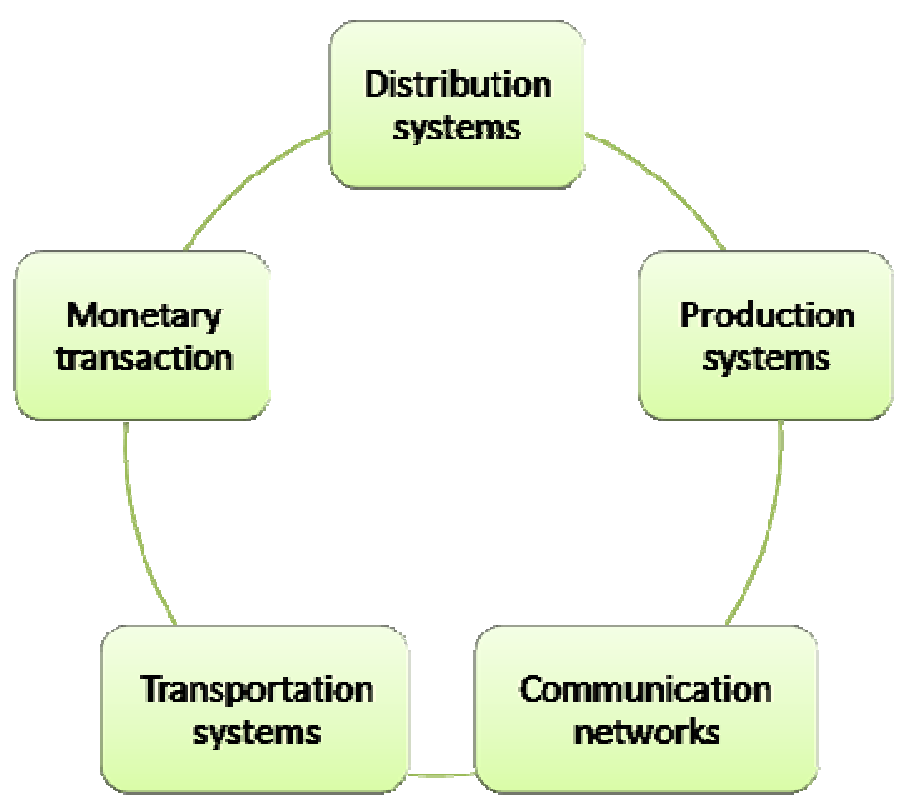

Figure 1. The Drug Trafficking System 


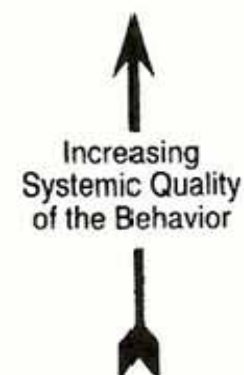

Multinational Crime:

White Collar Crime:

\section{Political}

Crime:

\section{Organized}

Crime:

Government Corruption:

\section{Professional} Crime:

\section{Conventional} Crime:
MULTINATIONAL CRIME

WHITE COLLAR CRIME

POLITICAL CRIME

ORGANIZED CRIME

GOVERNMENT CORRUPTION

PROFESSIONAL CRIME

CONVENTIONAL CRIME

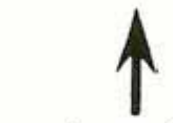

Increasing Integration with Economic, Political, and Other Institutions

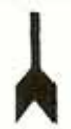

\section{Examples by Category}

terrorism, espionage, drug-trafficking, armstrafficking, money laundering, destabilization of foreign governments, assassination of foreign leaders.

bank fraud, embezzlement, insider trading, consumer fraud, price-fixing, criminal corporations, corporate bribery of public officials.

political coups and revolutions, Latin American "death squads," civil disobedience, voter fraud, civil rights violations.

gambling, prostitution, extortion, loan sharking, labor racketeering, truck hijacking.

police corruption, acceptance of bribes by public officials, extortion by public officials, judicial corruption.

theft, "fencing," shoplifting, confidence games, professional "hit men."

drunkenness, vagrancy, assault, rape, homicide, vandalism, arson, drug possession.

It shows seven major categories of crime, including multinational systemic crime, and contrasts the categories in terms of two variables. The first aspect relates to the relative degree to which each category involves systemic criminal behavior. The second aspect relates to the relative degree to which the individuals or groups in each category are integrated with the economic, political, social, and other institutions of larger society.

Figure 2. Categories of Crime (Martin and Romano, 1992:23) 